\title{
Летальність у хворих з ускладненим синдромом діабетичної стопи з проявами сепсису згідно з рекомендаціями «epsis-3»
}

\author{
С. Д. Шаповал, О. В. Трибушний, І. Л. Савон
}

Запорізька медична академія післядипломної освіти МОЗ України

\section{Lethality in patients with complicated diabetic foot syndrome and signs of sepsis in accordance to recommendations «Sepsis-3»}

\author{
S. D. Shapoval, O. V. Tribushnyi, I. L. Savon \\ Zaporizhzhya Medical Academy of Postgraduate Education
}

\section{Реферат}

Мета. Провести порівняльний аналіз показників летальності у хворих із сепсисом на тлі ускладненого синдрому діабетичної стопи (СДС) з урахуванням протоколу Погоджувальної конференції (1992) та рекомендацій III Міжнародного консенсусу з визначення сепсису та септичного шоку ( Sepsis-3»).

Матеріали і методи. Ретроспективно та проспективно проаналізовано 938 історій хвороби пацієнтів з ускладненим СДС. У 92 (9,8\%) паціентів захворювання було обтяжене сепсисом. Згідно з рекомендаціями «Sepsis-3» використовували нову шкалу під час обстеження біля ліжка - qSOFA.

Результати. Аналіз летальних випадків з урахуванням рекомендацій «Sepsis-3» показав, що деякі форми септичного процесу віднесені до ускладнених невиправдано, тобто їх кількісна оцінка за шкалою qSOFA не перевищувала 1 бала. Це дало можливість визначити сепсис причиною смерті у 5 (11,9\%) хворих, а септичний шок (СШ) - у 37 (88,1\%).

Висновки. Впровадження рекомендацій «Sepsis-3» в клінічну практику дасть змогу уникнути розбіжностей у постановці діагнозу. За допомогою шкали qSOFA можна швидко і без значних матеріальних витрат диференціювати сепсис і СШ.

Ключові слова: синдром діабетичної стопи; сепсис; летальність; рекомендації «Sepsis-3».

Abstract

Objective. To conduct analysis of lethality indices in patients with sepsis on background of complicated diabetic foot syndrome (DFS), taking into account a protocol of Conciliation Conference (1992) and recommendations of III International Consensus for determination of sepsis and septical shock ( $($ Sepsis-3»).

Materials and methods. There were analyzed 938 medical files of patients, suffering complicated DFS. In 92 (9.8\%) patients the disease was complicated by sepsis. In accordance to «Sepsis-3» recommendations a new scale was applied during examination near the bed - qSOFA.

Results. Analysis of lethal cases, taking into account «Sepsis-3» recommendations, have shown, that some forms of septic process were referred to complicated unjustifiably, i. e. their quantitative value in accordance to qSOFA scale did not exceeded 1 point. This gave possibility to determine a sepsis as the death cause in 5 (11.9\%) patients, and as a septic shock - in 37 (88.1\%). Conclusion. The «Sepsis-3» recommendations introduction into clinical practice would prevent disagreements while the diagnosis determination. It is possible without significant material expenses and rapidly to differentiate sepsis and septical shock, using qSOFA scale.

Keywords: diabetic foot syndrome; sepsis; lethality; recommendations «Sepsis-3».

Учасники симпозіуму «Сепсис та інфекції кровотоку» в рамках XVI Міжнародного конгресу з антимікробної терапії (2014) звернули увагу на те, що кожного року у світі реєструють $18-20$ млн. хворих із сепсисом, 4,5 - 6 млн. 3 яких помирає [1]. У 8 - 19\% хворих із сепсисом діагностують порушення вуглеводного обміну, а захворюваність на цукровий діабет (Цд) набула характеру пандемії [2]. Одним з найнебезпечніших ускладнень ЦД є СДС, частота якого щороку зростає на 2 - 6\% [3, 4]. Летальність при ускладненому СДС з проявами сепсису становила 51,9\% [5]. Сепсис був причиною смерті у 25\% хворих, тяжкий сепсис - у 77,8\%, СШ - у 71,4\%, синдром поліорганної недостатності (СПОН) - у 88,9\%.

Згідно 3 рекомендаціями «Sepsis-3» 3 класифікаціі сепсису вилучено тяжкий сепсис, а про СПОН не згадується [3]. На думку експертів, велика кількість визначень та термінів щодо сепсису, СШ та дисфункції органів призводить до розбіжностей між оцінками захворювань та показниками летальності, а синдром системної запальної відповіді (Systemis Inflammatory Response Syndrom SIRS) може бути просто відповіддю організму, яка часто є адаптованою $[4,6,7]$.

Мета дослідження: провести порівняльний аналіз показників летальності у хворих із сепсисом на тлі ускладненого СДС з урахуванням протоколу Погоджувальної конференції (1992) та рекомендацій («Sepsis - 3»).

\section{Матеріали і методи дослідження}

Проаналізовано 938 історій хвороби пацієнтів 3 ускладненим СДС. У 92 (9,8\%) пацієнтів захворювання було обтяжене сепсисом. Хворих лікували протягом 2006 - 2017 рр. у гнійно-септичному центрі міської клінічної лікарні № 3 м. Запоріжжя. Середній вік пацієнтів становив $(65,3 \pm 3,4)$ року.

У попередні роки сепсис діагностували за наявності вогнища інфекції, принаймні двох із чотирьох критері- 
їв SIRS та органної системної дисфункції. 3 кінця 2016 р. використовували нову шкалу при обстеженні біля ліжка - qSOFA, яка має набір простих критеріїв: частота дихання понад 22 за 1 хв, порушення свідомості та систолічний артеріальний тиск 13,3 кПа (100 мм рт. ст.) або менше.

Для клінічної оцінки сепсису органна дисфункція, зумовлена захворюванням, може бути визначена за підвищенням числа балів за шкалою qSOFA - 2 бали і більше, що відповідає госпітальній летальності більш як 10\%.

Причиною сепсису в переважної більшості хворих 3 ускладненим СДС була «волога» гангрена нижніх кінцівок.

Окрім збору анамнезу, загальноклінічних і біохімічних аналізів, обстеження включало додаткові методи: визначення концентрації в крові глікозильованого гемоглобіну, C-пептиду, прокальцитоніну. За допомогою імунологічного дослідження оцінювали клітинну та гуморальну ланки імунітету, неспецифічну резистентність організму. Вивчали стан перекисного окислення ліпідів (антиоксидантна система), інтерлейкіни. Серед інструментальних методів обстеження використовували рентгенографію, електрокардіографію, лазерну допплерівську флоуметрію. Також здійснювали бактеріологічне дослідження крові на стерильність.

Комплекс мікробіологічних досліджень мав за мету визначення чутливості мікроорганізмів (МО) до антибіотиків, якісного складу збудників та кількості мікробних тіл на 1 г тканини. Для визначення чутливості МО гнійного осередку до антибактеріальних препаратів у попередні роки застосовували стандартну диск-дифузійну методику, потім - експрес-метод С. Д. Шаповала, в останній час - автоматизовану систему Vitek-2.

Комплекс лікувальних заходів включав компенсацію вуглеводного обміну, використання нестероїдних протизапальних засобів, антибактеріальної терапії, препаратів для поліпшення метаболізму нервової тканини, дезагрегантів, низькомолекулярних гепаринів, дезінтоксикаційної терапії, корекцію супутньої патології, виконання хірургічних втручань і лікування ран.

Статистичний аналіз проводили 3 використанням програмного пакета «StatgraphicsPlusfor Windows 7.0».

\section{Результати}

Проаналізовані причини смерті 42 хворих із сепсисом на тлі ускладненого СДС згідно з класифікацією R. C. Bone [6] розподілили таким чином: сепсис - у 5 хворих, тяжкий сепсис - у 19, СШ - у 10, СПОН - у 8. Частота сепсису як причини летальності становила 11,9\%, його ускладнених форм - 88,1\%.

Проаналізувавши причини летальності з урахуванням рекомендацій «Sepsis - 3», встановили, що деякі форми септичного процесу були віднесені до ускладнених невиправдано, тобто кількісна оцінка за шкалою qSOFA не перевищувала 1 бала. Це дало можливість визначити сепсис причиною смерті у 5 (11,9\%) хворих, СШ - у 37 (88,1\%). Із 92 хворих з ознаками сепсису сепсис діагностовано у 31 (33,7\%), СШ - у 61 (66,3\%). Загальна летальність становила 45,7\%, при сепсисі - 16,1\%, при СШ - 60,7 \%. Одужали 26 (83,9\%) із 31 хворого із сепсисом і лише 24 (39,3\%) із 61 хворого із СШ.
Із 42 померлих хворих у 13 (30,9\%) операції не проводили, 5 із них категорично відмовилися від оперативного втручання, що документально підтверджено в історіях хвороби. Тривалість перебування цих пацієнтів у стаціонарі становила в середньому $(4,6 \pm 0,6)$ доби. Померли в перші години після госпіталізації у відділенні реанімації та інтенсивної терапії 8 хворих, стан яких був оцінений як неоперабельний.

Інші 29 померлих хворих оперовані під загальним знеболенням. Їм, як правило, виконували «високі» ампутації нижньої кінцівки з приводу «вологої» гангрени.

Під час автопсії у померлих виявили численні ураження органів і систем: бронхопневмонію, вогнищеву фіброзно-гнійну та абсцедивну пневмонію, гнійний плеврит, набряк легень, септичний міокардит, септичний нефрит, серозний інтерстиціальний гепатит, гіперплазію фолікулів, а також мієлоїдну дисплазію та септичну гіперплазію селезінки, інтерстиціальний та септичний нефрит, нефротичний некроз, енцефалопатію, мікроциркуляторні розлади та набряк головного мозку, дистрофічні та дегенеративні зміни внутрішніх органів.

У всіх померлих хворих гемокультура була позитивною, а тоді, коли вони перебували у стаціонарі, частота виявлення позитивної гемокультури не перевищувала 30\%. Однозначного пояснення цьому феномену немає. Можливо, позитивна гемокультура вважається такою в терміни до 10 діб з моменту забору крові на стерильність. Також імовірно, що забір крові під час автопсії не позбавлений порушення умов проведення цього дослідження.

\section{Висновки}

1. Щодо визначення тяжкості септичного процесу шкала qSOFA повністю корелює 3 класифікацією R. C. Bone.

2. Висока летальність у хворих із сепсисом без оперативного втручання свідчить про недоліки роз'яснювальної роботи медичного персоналу серед самих пацієнтів та їх близьких та, ймовірно, про похибки в проведенні інфузійно-трансфузійної й інотропної підтримки безпосередньо в стаціонарі.

\section{References}

1. Levyetal MM. The surviving sepsis campaign: results of an international guideline-based performance improvement program targeting severe sepsis. Intensive Care Med. 2010 Feb;36(2):222-31.

2. Rhodes A, Evans LE, Alhazzani W, Levy MM, Antonelli M, Ferrer R, et al. Surviving sepsis campaign: international guidelines for management of sepsis and septic shock: 2016. Intensive Care Med. 2017 Mar;43(3):304-77. doi: 10.1007/s00134-017-4683-6. Epub 2017 Jan 18. PMID: 28101605.

3. Byrne L, Van Haren F. Fluid resuscitation in human sepsis: Time to rewrite history? Ann Intensive Care. 2017 Dec;7(1):4. doi: 10.1186/ s13613-016-0231-8. Epub 2017 Jan 3..

4. Singer M, Deutschman CS, Seymour CW, et al. The Third International Consensus Definitions for Sepsis and Septic Shock (Sepsis-3). YAMA. 2016;315(8):801-10.

5. Trybushnyi OV, Shapoval SD, Savon IL, Novak VV. Analysis of lethality in complicated diabetic foot syndrome and sepsis. Klinichna khirurhiia. 2017;(1):58-60. [In Ukranian].

6. Bone RC. The pathogenesis of sepsis Ann. Int Med. 1991;115:457-69.

7. Dellingeretal RP. Surviving sepsis campaign: international guidelines for management of severe sepsis and septic shock: 2012. Crit Care Med. 2013 Feb;41(2):580-637. 